\title{
MENINGKATKAN KEMAMPUAN PROBLEM SOLVING MATEMATIK MELALUI PENDEKATAN KONTEKSTUAL PADA SISWA SMPN 5 WERA
}

\author{
Dusalan \\ Dosen Program Studi Pendidikan Matematika, STKIP Bima \\ Email: dusalanbima84@gmail.com
}

\begin{abstract}
Abstrak:
Seiring perkembangan Ilmu Pengetahuan dan Teknologi (IPTEK) semakin pesat, maka Kementerian Pendidikan dan Kebudayaan kemudian melaksanakan dan menyempurnakan Kurikulum (K-13) untuk dilaksanakan pada sekolah-sekolah walaupun pada kenyataannya masih banyak sekolah yang menemukan hambatan dalam penerapan Kurikulum 2013. Penelitian ini adalah penelitian tindakan kelas yang dilakukan di SMP Negeri 5 Wera yang bertujuan untuk meningkatkan kemampuan problem solving matematika melalui pendekatan kontekstual. Subjek penelitian ini adalah siswa Kelas $\mathrm{VII}_{1}$ SMP Negeri 5 Wera pada Tahun Pelajaran 2021/2022yang berjumlah 30 orang. Teknik pengambilan data dilakukan dengan menggunakan tes hasil belajar dengan kemampuan problem solving dan lembar observasi. Data yang terkumpul dianalisis secara kuantitatif dan kualitatif. Hasil yang diperoleh setelah diberikan tindakan yaitu: (1) Pada Siklus I, diperoleh skor rata-rata kemampuan problem solving matematika siswa adalah sebesar 66,67 dengan standar deviasi 18,189 dari skor ideal 100 dan berada pada kategori tinggi, (2) Pada Siklus II, diperoleh skor rata-rata kemampuan problem solving matematika siswa adalah sebesar 70,57 dengan standar deviasi 16,968 dari skor ideal 100 dan berada pada kategori tinggi. Peningkatan rata-rata dari Siklus I ke Siklus II menandakan adanya peningkatan kemampuan problem solving matematika siswa, (3) Jumlah siswa yang tuntas secara individu pada Siklus I sebanyak 17 orang siswa $(56,67 \%)$ dan pada Siklus II meningkat menjadi 21 orang siswa $(70,00 \%)$, dan (4). Sikap siswa terhadap pembelajaran matematika yang dilakukan cenderung mengalami perubahan ke arah yang lebih baik. Dari hasil penelitian ini dapat disimpulkan bahwa terjadi peningkatan kemampuan problem solving matematika pada siswa Kelas $\mathrm{VII}_{1}$ SMP Negeri 5 Wera setelah dilakukan pembelajaran dengan pendekatan kontekstual.
\end{abstract}

Kata Kunci: Kemampuan Problem Solving Matematika, Pendekatan Pembelajaran Kontekstual.

\section{PENDAHULUAN}

eiring perkembangan Ilmu Pengetahuan dan Teknologi (IPTEK) semakin pesat, maka Kementerian Pendidikan dan Kebudayaan kemudian melaksanakan dan menyempurnakan Kurikulum (K-13) untuk dilaksanakan pada sekolah-sekolah walaupun pada kenyataannya masih 
banyak sekolah yang menemukan hambatan dalam penerapan Kurikulum 2013. Menurut Mowendu, dkk, 2019 bahwa dalam pelaksanaan pendidikan harus sesuai dengan Kurikulum 2013 dengan memperhatikan setiap aspeknya, mulai dari perencanaan pembelajaran, proses pembelajaran sampai kepada proses penilaian. Ada empat standar penting yang perlu diperhatikan dalam proses pembelajaran oleh penyelenggara pendidikan khususnya sekolah, yakni; (1) standar kompetensi lulusan; (2) standar isi; (3) standar proses; (4) standar penilaian. Adanya standar pendidikan dan perubahan Kurikulum bertujuan untuk memajukan pendidikan Indonesia dalam berbagai bidangnya, tidak terkecuali dalam pendidikan matematika. Guru mata pelajaran matematika dituntut untuk melaksanakan pembelajaran sesuai dengan standar pendidikan dan Kurikulum 2013. Mata pelajaran matematika merupakan salah satu mata pelajaran penting untuk diajarkan di sekolah, terlebih lagi merupakan salah satu mata pelajaran yang diujikan secara nasional, sehingga dalam proses pelaksanaan pembelajaran membutuhkan model, pendekatan, strategi, metode, maupun teknik yang dilaksanakan pada kegiatan belajar mengajar.

Salah satu pembelajaran yang dapat meningkatkan kemampuan pemecahan masalah adalah pengajaran dan pembelajaran Kontekstual (CTL). Nurhadi (dalam Rusman, 2011:189) mengatakan bahwa Pembelajaran Kontekstual (Contextual Teaching And Learning) adalah sebuah konsep pembelajaran yang membantu guru mengkaitkan antara materi yang diajarkannya dengan situasi dunia nyata dan mendorong pelajar membuat hubungan antara materi yang diajarkannya dengan penerapannya dalam kehidupan mereka sebagai anggota keluarga dan masyarakat. Sedangkan menurut Sari, R. 2018 bahwa Adapun langkah-langkah pembelajaran Contextual Teaching and Learning (CTL) yang dapat diterapkan adalah sebagai berikut : (1) kembangkan pemikiran bahwa anak akan belajar dengan cara bekerja sendiri dan mengkontruksi sendiri pengetahuan keterampilan barunya, (2) laksanakan sejauh mungkin kegiatan inkuiri, (3) kembangkan sifat ingin tahu siswa dengan bertanya, (4) ciptakan "masyarakat belajar" (belajar dalam kelompok-kelompok), (5) hadirkan "model” sebagai contoh pembelajaran, (6) lakukan refleksi diakhir penemuan, (7) lakukan penilaian yang sebenarnya dengan berbagai cara (dalam penelitian yang dicapai adalah aspek pengetahuan, sikap dan keterampilan, penilaian diakhir penemuan). 


\section{eL-Muhbib}

\section{Jurnal Pemikiran dan Penelitian Pendidikan Dasar}

ISSN 2614-1051 Volume 5 Nomor 2 Desember 2021

Untuk meningkatkan kemampuan pemecahan masalah diperlukan suatu upaya salah satunya melalui pendekatan pembelajaran yang dapat merangsang siswa agar dapat belajar aktif, berorientasi pada proses, mengarahkan sendiri, mencari sendiri, dan reflektif sehingga siswa memiliki sikap mandiri dalam belajar serta mampu meningkatkan kemampuan pemecahan masalah. Oleh sebab itu, guru sebagai pendidik dituntut bisa menciptakan dan mengembangkan kemandirian anak didik serta mencipta konsep (Isnaeni, 2019). Peran guru bisa diwujudkan dengan mengajak anak didik belajar berbuat dan mengalami langsung serta keterlibatan secara aktif dalam lingkungan belajar. Sehingga dapat disimpulkan bahwa pendekatan kontekstual merupakan strategi pembelajaran yang menekankan kepada proses keterlibatan siswa secara penuh untuk dapat menemukan materi yang dipelajarinya dan menghubungkan dengan situasi kehidupan nyata sehingga mendorong siswa untuk dapat menerapkannya. Dalam pendekatan CTL siswa diharapkan dapat menguasai keterampilan berpikir dan memecahkan masalah matematik dengan baik. Pada penyajian masalah yang dekat dengan kehidupan nyata siswa, diharapkan siswa akan memiliki kemampuan terbiasa menghadapi masalah dalam kehidupan sehari-hari.

Berdasarkan wawancara penulis dengan beberapa siswa dan hasil pengamatan penulis secara langsung dalam kelas, bahwa orientasi pada jawaban akhir ini kemungkinan disebabkan karena siswa tidak memahami manfaat yang akan diperoleh jika mereka menyelesaikan suatu masalah matematika dengan langkah-langkah yang jelas. Jika mereka diperlihatkan cara menjawab dengan langkah-langkah yang jelas, sebagian kecil dari mereka menganggap itu terlalu panjang dan membuang waktu karena dengan menjawab seperti pada contoh di atas pun sudah mendapatkan nilai yang bagus. Hal ini berarti, sebenarnya mereka tahu langkah-langkahnya, akan tetapi tidak mereka tuliskan pada saat menyelesaikan soal. Akan tetapi sebagian besar dari siswa memang menganggap bahwa memang begitulah jawaban yang benar. Hal ini berarti, siswa tidak 
mengetahui proses untuk mendapatkan jawaban akhir dari soal yang mereka kerjakan.

Berdasarkan uraian di atas, maka penulis kemudian tertarik untuk meneliti sejauh mana penerapan pendekatan kontekstual mampu meningkatkan kemampuan problem solving matematika siswa melalui sebuah judul penelitian yakni "Meningkatkan Kemampuan Problem Solving matematika siswa melalui pendekatan kontekstual. Berdasarkan latar belakang di atas, tujuan penelitian ini adalah untuk meningkatkan kemampuan problem solving matematik melalui pendekatan kontekstual pada siswa SMPN 5 Wera.

\section{METODE PENELITIAN}

Penelitian ini adalah penelitian tindakan kelas (classroom action research) dengan tahapan-tahapan pelaksanaan meliputi perencanaan, pelaksanaan tindakan, observasi, evaluasi, dan refleksi secara berulang. Subyek penelitian ini adalah siswa Kelas VII 1 SMP Negeri 5 Wera tahun pelajaran 2021/2022 yang berjumlah 30 orang, terdiri atas 12 orang laki-laki dan 18 orang perempuan. Prosedur penelitian ini dilaksanakan dua siklus, tiap siklus terdiri atas beberapa tahap, yaitu tahap perencanaan, pelaksanaan tindakan, observasi dan evaluasi, dan refleksi. Selanjutnya Secara keseluruhan data yang terkumpul akan dianalisis secara kualitatif dan kuantitatif. Analisis data kuantitatif dilakukan dengan menggunakan penyajian data dalam bentuk tabel distribusi frekuensi atau daftar, Sedangkan data hasil observasi dianalisis secara kualitatif.

Adapun kriteria yang digunakan untuk menentukan kategori kemampuan problem solving matematika siswa didasarkan pada skala lima, dengan standar umum yang tentuKan Depdikbud (dalam Dusalan, 2017) yakni:

skor hasil belajar 0 - 34, dikategorikan sangat rendah, skor hasil belajar 35 - 54, dikategorikan rendah, skor hasil belajar 55 - 64, dikategorikan sedang skor hasil belajar 65 - 84, dikategorikan tinggi, dan skor hasil belajar 85 - 100, dikategorikan sangat tinggi.

Untuk melihat ketuntasan belajar secara klasikal digunakan kriteria ketuntasan belajar menurut standar Depdikbud (dalam Dusalan, 2017) yaitu 85\%, dengan kategori tuntas individu $65 \%$. 


\section{eL-Muhbib}

Jurnal Pemikiran dan Penelitian Pendidikan Dasar

ISSN 2614-1051 Volume 5 Nomor 2 Desember 2021

\section{HASIL DAN PEMBAHASAN}

Analisis Deskriptif Kemampuan Problem Solving Matematika Siswa pada Siklus I dan Siklus II. Deskripsi kemampuan problem solving matematika siswa diperoleh berdasarkan hasil tes siklus I dan siklus II. Hasil tes tersebut dapat disajikan dalam Tabel 4.1 berikut.

Tabel 4. 1 Statistik Skor Hasil Tes Kemampuan Problem Solving Matematika Siswa pada

Siklus I dan Siklus II

\begin{tabular}{l|c|c}
\hline \multirow{2}{*}{ Statistik } & \multicolumn{2}{|c}{ Nilai Statistik } \\
\cline { 2 - 3 } & Siklus I & Siklus II \\
\hline Subyek & 30 & 30 \\
Skor Ideal & 100 & 100 \\
Skor Tertinggi & 93 & 95 \\
Skor Terendah & 25 & 34 \\
Rentang Skor & 68 & 61 \\
Skor Rata-Rata & 66,67 & 70,57 \\
Standar Deviasi & 18,189 & 16,968 \\
\hline
\end{tabular}

Tabel di atas menunjukkan bahwa skor rata-rata perolehan siswa untuk tes akhir Siklus I adalah 70, 1 dari skor ideal 100, skor terendah 25 dan skor tertinggi 93 dengan rentang skor 68, untuk subyek pada Siklus 1 sebanyak 30 orang siswa. Sedangkan skor rata-rata perolehan siswa untuk tes akhir Siklus II adalah 71,60 dari skor ideal 100, untuk skor terendah 34 dan skor tertinggi 95 dengan rentang skor 61. Kemudian skor hasil tes kemampuan problem solving matematika siswa dikelompokkan ke dalam 5 kategori, maka diperoleh pada Tabel 4. 2 berikut.

Tabel 4.2 Distrbusi Frekuensi dan Persentase Skor Hasil Tes Kemampuan Problem Solving Matematika Siswa pada Siklus I dan Siklus II

\begin{tabular}{c|c|c|c|c|c|c}
\hline \multirow{2}{*}{ No. } & \multirow{2}{*}{ Skor } & \multirow{2}{*}{ Kategori } & \multicolumn{2}{|c|}{ Siklus I } & \multicolumn{2}{c}{ Siklus II } \\
\cline { 4 - 7 } & & & Frekuensi & Persentase & Frekuensi & Persentase \\
\hline 1 & $0-34$ & Sangat & 1 & $3,33 \%$ & 1 & $3,34 \%$ \\
2 & $35-54$ & Rendah & 6 & $20,00 \%$ & 4 & $13,33 \%$ \\
3 & $55-64$ & Rendah & 6 & $20,00 \%$ & 4 & $13,33 \%$ \\
4 & $65-84$ & Sedang & 12 & $40,00 \%$ & 16 & $53,33 \%$ \\
5 & $85-$ & Tinggi & 5 & $16,67 \%$ & 5 & $16,67 \%$ \\
& 100 & Sangat & & & & \\
& Tinggi & & & & \\
\hline
\end{tabular}


Pada tabel 4.2 terlihat bahwa dari 30 orang siswa yang menjadi subyek penelitian terdapat 1 orang atau 3,33\% siswa dalam kategori sangat rendah, 6 orang atau 20,00\% siswa dalam kategori rendah, 6 orang atau 20,00\% siswa dalam kategori sedang, 12 orang atau 40,00\% siswa dalam kategori tinggi, dan 5 orang atau 16,67\% siswa dalam kategori sangat tinggi. Sedangkan untuk siklus II terdapat 1 orang atau 3,34\% siswa yang termasuk dalam kategori sangat rendah, 4 orang atau 13,33\% siswa yang termasuk dalam kategori rendah, 4 orang atau $13,33 \%$ siswa yang termasuk dalam kategori sedang, 16 orang atau 53,33\% siswa memperoleh skor yang termasuk dalam kategori tinggi, dan 5 orang atau 16,67\% siswa yang masuk dalam kategori sangat tinggi. Selanjutnya skor hasil tes yang menggambarkan kemampuan problem solving matematika siswa, maka persentase ketuntasan belajar siswa pada Siklus I dan Siklus II dapat dilihat pada Tabel 4.3 berikut.

Tabel 4. 3 Deskripsi Ketuntasan Belajar pada Siklus I dan Siklus II

\begin{tabular}{c|c|c|c|c|c}
\hline \multirow{2}{*}{$\begin{array}{c}\text { Persentase } \\
\text { Skor }\end{array}$} & \multirow{2}{*}{ Kategori } & \multicolumn{2}{|c|}{ Siklus I } & \multicolumn{2}{c}{ Siklus II } \\
\cline { 3 - 6 } & & Frekuensi & Persentase & Frekuensi & Persentase \\
\hline $0 \%-64 \%$ & Tidak & 13 & $43,33 \%$ & 9 & $30,00 \%$ \\
$65 \%-100 \%$ & $\begin{array}{c}\text { Tuntas } \\
\text { Tuntas }\end{array}$ & 17 & $56,67 \%$ & 21 & $70,00 \%$ \\
& & & & \\
\hline
\end{tabular}

Pada tabel 4. 3, terlihat bahwa pada Siklus I persentase ketuntasan kelas sebesar $43,33 \%$ atau 13 orang siswa dalam kategori tidak tuntas dan 56,67\% atau 17 orang dalam kategori tuntas. Sedangkan pada siklus II menunjukkan bahwa persentase ketuntasan belajar siswa sebesar 30,00\% atau 9 orang siswa termasuk dalam kategori tidak tuntas dan $70,00 \%$ atau 21 orang siswa termasuk dalam kategori tuntas.

\section{Refleksi Terhadap Proses Pelaksanaan Tindakan tiap Siklus}

\section{Siklus I}

Pada awal pelaksanaan pembelajaran nampak sekali kurangnya antusiasme siswa dalam mengikuti proses pembelajaran, karena kesannya bahwa matematika adalah pelajaran yang sulit, hal ini sangat nampak dari jawaban siswa ketika diminta memberikan pendapat tentang pelajaran matematika yang selama ini mereka terima. Oleh karena itu, pada awal-awal pelaksanaan Siklus I, setiap pertemuan selalu disisipkan cerita-cerita menarik yang berkaitan dengan matematika atau teka-teki/permainan matematika sehingga dapat menarik minat siswa pada pembelajaran matematika. Penyajian materi pelajaran yang diselingi 


\section{eL-Muhbib \\ Jurnal Pemikiran dan Penelitian Pendidikan Dasar \\ ISSN 2614-1051 Volume 5 Nomor 2 Desember 2021}

dengan cerita-cerita atau permainan matematika ternyata berdampak positif pada antusiasme siswa dalam mengikuti proses pembelajaran, akan tetapi, berdampak negatif pada efisiensi waktu. Pelaksanaan kegiatan pada Siklus I, proses pembelajaran lebih banyak menggunakan kelompok-kelompok heterogen yang beranggotakan 5-6 orang. Kegiatan belajar secara berkelompok ini sangat disenangi oleh sebagian besar siswa karena merupakan hal sangat jarang mereka lakukan selama ini. Keaktifan siswa terlihat cukup memuaskan dalam proses pembelajaran. Banyak siswa yang aktif saat kegiatan pembelajaran berlangsung seperti aktif bertanya, menjawab pertanyaan, mengerjakan soal di papan tulis, meminta bimbingan guru dan kerjasama dalam mengerjakan LKS serta pada saat mendemonstrasikan hasil kerja kelompok mereka. Meskipun demikian, masih terlihat siswa yang bersikap pasif yang hanya diam bahkan melakukan kegiatan lain pada saat proses pembelajaran sedang berlangsung. Siswa yang demikian umumnya kurang memahami materi yang diberikan dan cenderung menghindar jika guru mendatanginya untuk dibimbing bahkan dengan sengaja bersikap seolah-olah siswa sudah memahami materi, terlebih jika siswa tersebut diberi kesempatan ke depan kelas untuk mengerjakan soal-soal.

Walaupun metode pembelajaran ini sangat bagus untuk mengaktifkan siswa, akan tetapi kegiatan berkelompok ini cukup menyulitkan bagi peneliti. Suasana kelas menjadi ramai, siswa yang memang masih membawa sifat anakanaknya cenderung berdiskusi dan bercerita dengan suara yang relatif besar dan jika menemukan kendala akan berteriak memanggil guru untuk meminta bimbingan. Kendala lain pada kegiatan belajar kelompok ini adalah membutuhkan waktu yang relatif lebih lama jika dibandingkan dengan pembelajaran langsung. Dengan tetap memperhatikan rambu-rambu pendekatan pembelajaran kontekstual, proses pembelajaran juga terkadang menggunakan metode pembelajaran langsung. Proses pembelajaran dengan metode ini relatif lebih bisa membuat suasana kelas menjadi tenang. Akan tetapi, keaktifan siswa untuk menjawab soal di papan tulis cenderung berkurang. Hal ini disebabkan karena siswa kurang percaya diri dengan jawaban yang mereka peroleh sehingga mereka cenderung takut untuk mengacungkan jari dan lebih memilih untuk membiarkan temannya yang mereka anggap lebih pintar untuk maju. Jawaban dari temannya yang maju itulah yang kemudian mereka cocokkan dengan jawabannya sendiri. 


\section{Siklus II}

Pada Siklus II, kegiatan pembelajaran tidak jauh berbeda dengan Siklus I dimana Siklus II merupakan perbaikan dari tindakan yang telah dilakukan, setelah diadakan refleksi hasil pelaksanaan Siklus I. Pada Siklus Ini terlihat jelas banyaknya siswa yang memperhatikan materi mengalami peningkatan, sedangkan siswa yang melakukan kegiatan lain pada saat proses pembelajaran berlangsung semakin berkurang. Pada pertemuan berikutnya hingga akhir Siklus II, terlihat bahwa proses pembelajaran dengan pendekatan kontekstual sesuai dengan apa yang diharapkan, dimana siswa lebih aktif mengerjakan tugas atau LKS secara berkelompok serta mengerjakan soal di papan tulis. Secara umum, dapat dikemukakan bahwa perhatian dan keaktifan siswa memperlihatkan kemajuan. Peningkatan rata-rata hasil belajar siswa terlihat jelas dengan memperhatikan nilai-nilai ujian pada Siklus I dan Siklus II. Untuk itu kemampuan siswa menerima materi pelajaran matematika lebih baik lagi, demikian pula keaktifan siswa dalam menyelesaikan soal-soal latihan atau materi yang diterima semakin meningkat pula.

Dari hasil analisis deskriptif di atas menunjukkan bahwa setelah pemberian tindakan selama dua siklus rata-rata skor hasil belajar siswa mengalami peningkatan. Pada Siklus I, rata-rata skor siswa adalah 66,67 dengan standar deviasi adalah 18,189, dengan skala kategori tinggi dan rata-rata skor siswa pada siklus II meningkat menjadi 70,57 dengan standar deviasi 16,968, dengan skala kategori tinggi. Hal ini berarti terjadi peningkatan pada kemampuan problem solving matematika siswa kelas $\mathrm{VII}_{1}$ SMP Negeri 5 Wera dalam mata pelajaran matematika, yaitu dari skor rata-rata 66,67 menjadi 70,57 pada kategori yang sama yaitu kategori tinggi setelah menerapkan kemampuan problem solving dengan pendekatan kontekstual dengan baik pada proses pembelajaran siswa. Lebih lanjut hasil analisis deskriptif menunjukkan bahwa terjadi peningkatan jumlah siswa yang tuntas belajar setelah pemberian tindakan selama dua siklus, yaitu pada Siklus I terdapat 17 orang siswa $(56,67 \%)$ yang tuntas belajar dan pada Siklus II meningkat menjadi 21 orang siswa (70,00\%). Walaupun demikian, ketuntasan klasikal yang diharapkan ternyata belum dapat tercapai.

\section{SIMPULAN}

Berdasarkan hasil penelitian dan pembahasan dapat ditarik kesimpulan bahwa setelah diterapkan pada pembelajaran dikelas selama 2 siklus yaitu kemampuan problem solving matematik melalui pendekatan kontekstual pada 


\section{eL-Muhbib \\ Jurnal Pemikiran dan Penelitian Pendidikan Dasar \\ ISSN 2614-1051 Volume 5 Nomor 2 Desember 2021}

siswa Kelas VII1 SMPN 5 Wera mengalami peningkatan dan efektif dalam meningkatkan kemampuan problem solving matematik siswa. Dalam upaya meningkatkan kemampuan problem solving matematika siswa melalui penelitian ini disarankan: 1) Guru hendaknya menerapkan pendekatan kontekstual dalam pembelajaran matematika dengan baik dan benar berdasarkan langkah-langkah pembelajarannya. 2) guru hendaknya mengadakan variasi dalam memberikan situasi di dalam kegiatan pembelajaran sehingga tidak menimbulkan kejenuhan pada diri siswa. 3) Untuk meminimalisir persepsi bahwa matematika adalah pelajaran yang sulit dan membosankan, maka cerita-cerita atau permainan matematika sangat bagus untuk disisipkan dalam kegiatan pembelajaran matematika. 4) Bagi peneliti selanjutnya yang menerapkan kemampuan problem solving melalui pendekatan kontekstual dengan memperhatikan langkah-langkah pembelajaran yang dapat memacu motivasi belajar siswa dengan baik.

\section{DAFTAR PUSTAKA}

Arafani, EL., Herlina, E., Zanthy, SL. (2019). Peningkatan Kemampuan Memecahkan Masalah Matematik Siswa Smp Dengan Pendekatan Kontekstual. Jurnal Cendekia (Jurnal Pendidikan Matematika), 1(1), 323-331

Dusalan, D. (2017). Kontribusi Konsep Diri Dan Perhatian Orang Tua Terhadap Hasil Belajar Matematika Siswa Kelas X Sma Di Kecamatan Wera Bima. Supermat (Jurnal Pendidikan Matematika), 1(1), 1-9.

Isnaeni, S., Ansori, A., Akbar, P., \& Bernard, M. (2019). Analisis Koneksi Matematis Siswa Smp Pada Materi Persamaan Dan Pertidaksamaan Linear Satu Variabel. Journal On Education, 1(1), 309-316.

Lastuti, S. (2019). Identifikasi Kemampuan Pemecahan Masalah Matematika Mahasiswa Calon Guru SD di STKIP Taman Siswa Bima dan Cara Pengembangannya. Jurnal Pendidikan MIPA, 9(2), 101-111.

Marpaung, Y. 2003. Perubahan Paradigma Pembelajaran Matematika Sekolah. Makalah Seminar Nasional Pendidikan Matematika di Universitas Sanata Darma Yogyakarta. Tidak diterbitkan.

Mulyasa, E. 2005. Menjadi Guru Profesional Menciptakan Pembelajaran Kreatif dan Menyenangkan. P. T. Rosda Karya: Bandung.

Mulyadin, E., Sowanto, S., \& Dusalan, D. (2020). Pengembangan Perangkat Pembelajaran CIRC (Cooperative Integrated Reading And Composition) dalam Meningkatkan Pemahaman Matematis Pada Materi Perbandingan Siswa SMP. SUPERMAT (Jurnal Pendidikan Matematika), 4(1), 40-51. 
Mutmainah, M., Dusalan, D., \& Muchlis, M. (2018). Pengaruh Pembelajaran Problem Based Learning Terhadap Kreativitas Matematika Siswa Pada Kelas Viii Unggulan Mtsn 1 Makassar. Supermat (Jurnal Pendidikan Matematika), 2(2), 18-28.

Mowendu, AL., Slameto, \& Dwikurnaningsih, Y. (2019). Evaluasi Implementasi Kurikulum 2013 Pada Mata Pelajaran Matematika Di Smp Negeri. Jurnal Manajemen Pendidikan (Jurnal Magister Manajemen Pendidikan Matematika Fkip Universitas Kristen Satya Wacana), 2(2), 74-88.

Nurhadi. Yasin, B., \& Senduk, A. G. 2004. Pendekatan Kontekstual (Contextual Teaching and Learning/CTL) dan Penerapannya dalam KBK. Penerbit Universitas Negeri Malang (UM Press): Malang.

Rusman. (2011). Model-model Pembelajaran. PT. Raja Grafindo Persada. Jakarta Sari, R. (2018). Pengaruh Model Problem Solving Dengan Pendekatan Ct1 (Contextual Teaching And Learning) Terhadap Keaktifan Dan Hasil Belajar Siswa Pada Mata Pelajaran Fisika. Gravity Edu (Jurnal Pendidikan Fisika), 1(2), 6-10.

Sukestiyarno, Y. L. 2003. Operasional Penerapan CTL (Contextual Teaching and Learning) dalam Bidang Matematika di Sekolah Sesuai Tuntutan KBK (Kurikulum Berbasis Kompetensi). Makalah Seminar Nasional Pendidikan Matematika di Universitas Sanata Darma Yogyakarta. Tidak diterbitkan. 